\title{
Polycyclic Aromatic Hydrocarbons (PAHs) Sample Preparation and Analysis in Beverages: A Review
}

\author{
Pau Lian Peng ${ }^{1} \cdot$ Lee Hoon Lim ${ }^{1}$
}

Received: 16 July 2021 / Accepted: 18 November 2021 / Published online: 1 January 2022

(C) The Author(s) 2021

\begin{abstract}
The monitoring of food contaminants is of interests to both food regulatory bodies and the consumers. This literature review covers polycyclic aromatic hydrocarbons (PAHs) with regard to their background, sources of exposures, and occurrence in food and environment as well as health hazards. Furthermore, analytical methods focusing on the analysis of PAHs in tea, coffee, milk, and alcoholic samples for the last 16 years are presented. Numerous experimental methods have been developed aiming to obtain better limits of detections (LODs) and percent recoveries as well as to reduce solvent consumption and laborious work. These include information such as the selected PAHs analyzed, food matrix of PAHs, methods of extraction, cleanup procedure, LOD, limits of quantitation (LOQ), and percent recovery. For the analysis of tea, coffee, milk, and alcoholic samples, a majority of the research papers focused on the 16 US Environmental Protection Agency PAHs, while PAH4, PAH8, and methylated PAHs were also of interests. Extraction methods range from the classic Soxhlet extraction and liquid-liquid extraction to newer methods such as QuEChERS, dispersive solid-phase microextraction, and magnetic solid-phase extraction. The cleanup methods involved mainly the use of column chromatography and SPE filled with either silica or Florisil adsorbents. Gas chromatography and liquid chromatography coupled with mass spectrometry or fluorescence detectors are the main analytical instruments used. A majority of the selected combined methods used are able to achieve LODs and percent recoveries in the ranges of $0.01-5 \mathrm{ug} / \mathrm{kg}$ and $70-110 \%$, respectively, for the analysis of tea, coffee, milk, and alcoholic samples.
\end{abstract}

Keywords Polycyclic aromatic hydrocarbons $\cdot$ Tea $\cdot$ Coffee $\cdot$ Milk $\cdot$ Alcohols $\cdot$ GC-MS

\section{Introduction}

Food contaminants such as pesticide residues, mycotoxins, and environmental pollutants can be commonly found in raw materials for feed and food production processes due to non-identical worldwide weather, harvesting, and storage conditions (Nielen and Marvin 2008). In addition, food preparation steps such as cooking at a high temperature will potentially release food processing contaminants such

Pau Lian Peng

19m8962@ubd.edu.bn

Lee Hoon Lim

leehoon.lim@ubd.edu.bn

1 Chemical Sciences, Faculty of Science, Universiti Brunei Darussalam, Tungku Link Road, Bandar Seri Begawan BE1410, Brunei Darussalam as polycyclic aromatic hydrocarbons (PAHs), acrylamide, and heterocyclic amines into the food (Rey-Salgueiro et al. 2009). This has led to an increasing interest in the monitoring of these contaminants in food, which can be quite challenging due to the complexity of food matrixes in food products.

In this review, one of the food processing contaminants, namely PAHs, will be the main focus. The ever increasing in the number of articles regarding the presence of PAHs in foodstuffs has garnered attention worldwide due to its ubiquity, and the resulting health hazards that can arise through ingestion, inhalation, and dermal contact with PAHs. This review summarizes the studies carried out by researchers who utilized different extraction methods to determine the presence of PAHs in beverages. In addition, researchers are also focusing on developing simpler and alternative extraction, cleanup, and analytical methods, which yield good recoveries and limits of detection (LODs). 


\section{Background}

PAHs are highly hydrophobic and organic lipophilic compounds with fused aromatic rings mainly composed of hydrogen and carbon atoms (Essumang et al. 2013). These compounds are semi- or non-volatile in nature, ubiquitous, and known for their carcinogenic and mutagenic potential (Ledesma et al. 2014). They range from two to up to ten fused aromatic rings (Huang and Penning 2014). Molecular sizes of PAHs determine their vapor pressures and therefore affecting their dispersal of in the environment. Heavy PAHs (four or more fused rings) have lower volatility and adsorb on combustion particles like soot whereas light PAHs (less than four fused rings) are extremely volatile compounds, existing mostly in their gaseous state and widely distributed (Lammel et al. 2010).

Sander and Wise (2020) stated that 660 PAHs were revealed according to the NIST Special Publication 922 "Polycyclic Aromatic Hydrocarbon Structure Index." Nevertheless, 16 PAHs such as naphthalene (NPH), acenaphthylene (ACY), acenaphthene (ACP), fluorene (FLR), phenanthrene (PHE), anthracene (ANT), fluoranthene (FA), pyrene (PY), chrysene (CHR), benz(a)anthracene (BaA), benz(b)fluoranthene (BbFA), benzo(k)fluoranthene (BkFA), benz(a)pyrene (BaP), indeno(1,2,3-cd)pyrene (IP), benzo(g,h,i)perylene (BghiP), and dibenzo(a,h)anthracene (DBahA) were being chosen as priority pollutants by the United States Environmental Protection Agency (USEPA) (Tamakawa 2004). The 16 USEPA PAHs are mostly hydrophobic and non-polar solids with high melting and boiling points.

\section{The Formation Mechanism of PAHs}

PAHs are known to be formed by condensation processes of smaller organic compounds in absence of oxygen by either pyrolysis or pyrosynthesis (Ciemniak et al. 2019). Pyrolysis (pyro meaning "fire" and lysis for "separating") is the decomposition of organic material at elevated temperatures in an inert atmosphere and it involves irreversible change of chemical composition and physical phase (Viegas et al. 2019). At elevated temperatures above $200{ }^{\circ} \mathrm{C}$, pyrolysis will occur and organic compounds will be fragmented, hence producing free radicals which unite to form stable polycyclic aromatic compounds (pyrosynthesis). The amount of PAHs formed is directly proportional with an increase in temperature, which affects both the structure and diversity of PAHs formation (Chen and Chen 2001).

\section{Toxicological Aspects and Human Health Effects}

The major health concern that arises from the ingestion of food contaminated with PAHs is the increased in risks of cancer (Huang and Penning 2014). Nevertheless, it was found that some PAHs are not carcinogenic on their own but may function as co-carcinogens (do not usually cause cancer on their own but promote the activity of other carcinogens in causing cancer). From the research experiments carried out on animals, the common areas of cancer formation after the consumption of PAHs are located within the digestive system (Huang and Penning 2014). However, PAHs tend to exist in complex mixtures of varying compositions, and hence the evaluation of their associated health risks can be challenging.

The Agency for Toxic Substances and Disease Registry (ATSDR 2009a) shared that besides contributing to the carcinogenicity and mutagenicity of the PAHs in experimented animals, certain PAHs can produce many other detrimental health effects, including reproductive, developmental, immunotoxic, and neurologic effects. However, the carcinogenic, mutagenic, and teratogenic effects of PAHs will only take place if a PAH-DNA adduct is formed (Höner 2001; Huang and Penning 2014). Developmental toxicity of PAHs occurs because PAHs have lipophilic characteristics enabling them to reach the embryo and fetus by passing through the placental barrier of a pregnant woman (Herbstman et al. 2012). In addition, immunotoxic effects from the PAHs are highly associated with immunosuppression where the exposed individual will have a higher susceptibility to infectious diseases and the formation of cancers (Huang and Penning 2014).

The International Agency of Research on Cancer (IARC) has categorized PAHs into five groups: Group 1 (carcinogenic to humans), Group 2A (probably carcinogenic to humans), Group 2B (possibly carcinogenic to humans), Group 3 (not classifiable regarding its carcinogenicity towards humans), and Group 4 (probably not carcinogenic to humans). $\mathrm{BaP}$ is one of the most carcinogenic compounds and has been regrouped from Group 2A to Group 1 and CHR has been reclassified from Group 3 to Group 2B, whereas $\mathrm{BaA}$ was reassigned from 2A to $2 \mathrm{~B}$ (Ishizaki et al. 2010).

\section{Sources and Occurrence of PAHs}

PAHs are ubiquitous and diffusion into the environment can occur easily through both natural events and man-made processes. The World Health Organization (WHO 1998) stated that the primary anthropogenic products involved are from 
petroleum refineries, industrial machinery manufacturing, motor vehicle exhausts, coke production, barbeque smoke, tobacco smoke, and etc. Considerable amounts of PAHs are also found to be generated from natural sources, for instance, volcanic activity and forest fires. Furthermore, PAHs can be found in water (Rey-Salgueiro et al. 2009; Zhang et al. 2012), soil (Shang et al. 2014; Yu et al. 2019), air (Lammel et al. 2010), foods (García-Falcón et al. 2005a; YebraPimentel et al. 2012), and street dust (Lorenzi et al. 2011; Gope et al. 2018). Consequently, the careful monitoring of PAHs is vital as certain PAHs have been found to be carcinogens in experimental animals, indicating the possible carcinogenic effects on humans (ATSDR 2009).

\section{Occurrence of PAHs in Food}

Natural sources and environmental pollution such as the deposition of airborne particulates to the soil and surface of plants can lead to the contamination of food with PAHs (Killian et al. 2000; Smith et al. 2001). Research has discovered that around 79-99\% of mankind's susceptibility to PAHs were contributed by food consumption and it has been estimated that the possible total intake of PAHs through food is $2.5 \mu \mathrm{g} /$ day (Menzie et al. 1992). Roasting, toasting, baking, smoking, frying, and baking are some of the food preparation techniques that can cause the formation of PAHs (Codex Alimentarius Commission 2005; European Commission 2002; Perelló et al. 2009). Moreover, PAHs have been found in food following preservation processes such as traditional drying and curing of food (de Vos et al. 1990). Various food samples, including roasted coffee (Houessou et al. 2006; Guatemala-Morales et al. 2016), tea (Lin et al. 2005; Wu et al. 2020), milk (Aguinaga et al. 2008; Sun et al. 2020), alcoholic beverages (Menezes et al. 2015; Singh et al. 2016), oils (Rodríguez-Acuña et al. 2008; Yousefi et al. 2018), smoked meat (Jira et al. 2008; Zachara et al. 2017), smoked cheese (Guillén and Sopelana 2005; Gul et al. 2015), smoked fish (Lund et al. 2009; Mahugija and Njale 2018), fruits (Jánská et al. 2006; Paris et al. 2018), and vegetables (Jánská et al. 2006; Jia et al. 2018) were found to contain PAHs at $\mu \mathrm{g} / \mathrm{kg}$ concentrations.

The Scientific Opinion of the Panel on Contaminants in the Food Chain indicated that $\mathrm{BaP}$ alone was insufficient to gauge the amount of PAHs present in food (Alexander et al. 2008). Therefore, they suggested using PAH2, PAH4, and PAH8 to estimate the margins of exposure (MOE). PAH2 indicates $\mathrm{BaP}$ and $\mathrm{CHR}$, whereas, PAH4 means BaP, BaA, Chry, and BbFA and PAH8 includes $\mathrm{BaP}, \mathrm{BaA}, \mathrm{BkFA}, \mathrm{CHR}, \mathrm{BbFA}, \mathrm{DBahA}, \mathrm{BghiP}$, and IP (Alexander et al. 2008).

\section{PAHs Found in Beverages}

In the past 16 years, extensive research studies have been carried out by scientists to analyze the amount of PAHs in various beverages such as tea, coffee, milk, and alcoholic beverages as PAHs are formed during their production processes. The following sections provide a summary of the sources of PAHs in these beverages.

\section{Tea}

Tea is the second most consumed non-alcoholic beverage, the first being water (Benson et al. 2018). The Food and Agriculture Organization (FAO) of the United Nations (FAO 2012) stated that around 4 million tonnes of tea were consumed in 2010 and in the last 10 years; the quantity of tea produced has increased to an approximate of 5.35 million tonnes in 2013 (FAO 2015). Tea is known to be refreshing, medicinally beneficial, and an antioxidant, as well as having mild stimulant properties and pleasant aromas (Kuroda and Hara 1999; Pittler 2005). Agricultural products including raw ingredients of tea have a likelihood of being contaminated with contaminants such as PAHs. An example would be PAHs that are in the gaseous state or PAHs that are bounded to particulates in the air, which could be easily deposited on the leaves of tea and hence causing accumulation to occur (Jánská et al. 2006). Moreover, the accumulation of hydrophobic PAHs in fruit and herbal teas is possible due to the presence of lipophilic compounds, such as essential oils (Schlemitz and Pfannhauser 1997). PAHs are produced during the fresh leaf treatment process, such as the burning of oil, coal, and wood for drying or roasting of tea leaves (Lin et al. 2005). The analysis of PAHs in tea can be quite challenging as tea contains various co-extractives, for example, high levels of chlorophyll, polyphenols, organic acids, caffeine, sugars, and pigments. Nevertheless, the concentrations of co-extractives are highly dependable on the types of tea. Black teas are considered to have a complicated matrix as there is a high amount of interfering substances. The EU Commission (2011) has established regulated maximum levels of allowable PAHs on various food products, but none have been accepted and acknowledged for teas yet. Nevertheless, the maximum contaminant level (MCL) of PAHs in drinking water was set to be as follows: (1) $0.1 \mathrm{ppb}$ for $\mathrm{BaA}$, (2) $0.2 \mathrm{ppb}$ for $\mathrm{BaP}, \mathrm{BbFA}, \mathrm{BkFA}, \mathrm{CHR}$, (3) $0.3 \mathrm{ppb}$ for DBahA, and (4) $0.4 \mathrm{ppb}$ for IP (ATSDR 2009b).

\section{Coffee}

Coffee is widely consumed around the world and chemical substances such as proteins, carbohydrates, fats, vitamins, water, minerals, flavoring substances, organic acids, and 
caffeine are present in coffee beans (Lee and Shin 2010). Roasting is an important step in order to bring out the flavor, aroma, and color of coffee and is normally carried out with temperatures of $120-230{ }^{\circ} \mathrm{C}$ (Tfouni et al. 2012). On the other hand, roasting can also prompt the production of unwanted and hazardous compounds such as PAHs, acrylamide, and furan (Tfouni et al. 2013). Additionally, coffee drinks that were brewed with PAH-contaminated green coffee beans might contain PAHs as well (Houessou et al. 2008). Nevertheless, for coffee and coffee substitutes, no maximum levels of PAHs have been established by the European Union (EU) Commission (Sadowska-Rociek et al. 2015).

\section{Milk}

Milk is an important essential dairy product required by humans and it contributes to the dietary intake of zinc, vitamin B12, magnesium, calcium, pantothenic acid, and selenium (Raza and Kim 2018). In dairy farming process, animal feed are at risk of contamination from water, soil, and air; organic contaminants such as PAHs can be transferred from the animals that have fed on contaminated feeds through different routes such as milk, urine, and feces (Grova et al. 2002). PAHs that are ubiquitous in the environment and are lipophilic have a huge tendency to be distributed in milk (Zhao et al. 2017, 2018). Hence, human diets will be contaminated with PAHs upon the ingestion of milk containing PAHs.

Various milk samples undergo processes such as pasteurization and ultra-high-temperature processing (UHT). Results have shown that all the raw milk samples analyzed contained PAHs, but higher concentrations were observed in the UHT and pasteurized milk. This indicates that these heat treatment procedures have an effect on raising the levels of PAHs in milk (Naccari et al. 2011).

\section{Alcoholic Beverages}

Spirits are high-degree alcoholic beverages with an average alcohol content of $40 \% \mathrm{v} / \mathrm{v}$ and they are obtained from the distillation of low-degree alcoholic beverages (alcohol which are produced from the fermentation of sugar) (Cacho et al. 2016). Some examples of spirits are cachaça, gin, vodka, whisky, brandy, and rum. The WHO (2014) reported that around $9.2 \mathrm{~L}$ of pure alcohol is consumed per capita per year in the USA. However, researchers have discovered that PAHs can contaminate some of the spirits through various manufacturing processes. Cachaça is a Brazilian alcoholic distillate manufactured from fermented sugar cane juice and is ranked as the third largest distilled spirit consumed worldwide (Cardoso et al. 2004). Before the harvesting of the sugar canes take place, the sugar canes are being burnt to evaporate off the water in the stalk and to increase the sugar weight. This can contribute to the production of PAHs as the incomplete combustion of organic matters occur during this process and may be attached to the stalks of the sugar canes, hence contaminating the sugar cane juice during processing (Galinaro et al. 2007).

Rum is commonly produced from the distillation of fermented sugar cane molasses (by product of refining sugar cane) or sugar cane juice. Similar to the cachaça production process, the sugar cane is first burnt which creates the main source of contamination for PAHs (Riachi et al. 2014). In contrast, the flavor of whisky is developed during the aging process which involves smoking or charring oak wooden casks. This can lead to the migration of PAHs present in the woods to the whisky (Chinnici et al. 2007; Da Porto et al. 2006).

The production of cereal-based beverages such as beer, which is the most commonly consumed alcoholic beverage in the world, involves the roasting and toasting of barley, which are the main source of PAHs (Anderson et al. 2019; Rascón et al. 2019). Wine is commonly aged by being stored inside wood barrels or in steel tanks containing wood chips (Rascón et al. 2019). Chinnici et al. (2007) reported that the wood of the barrels and chips is naturally aged by the weather for 1-3 years, but are also toasted with open oak fires and other methods of toasting (electrical and convective heating), which will generate a significant amount of PAHs.

\section{Analytical Methods for PAH Determination}

Different methods have been validated for the extraction of PAHs in accordance with the matrixes of each food item since there is no existence of standardized methods for a particular matrix. Multiple extractions steps together with preconcentration procedures need to be carried out for PAHs that are in the ppb levels. In addition, there are challenges in obtaining repeatability for PAHs with two or three aromatic rings. Therefore, rapid, simple, and dependable analytical methods need to be developed so that precise deduction of contaminants in foods can be achieved. From this, the actual exposure of humans to PAHs in food can be evaluated.

\section{Sample Preparation}

Prior to the PAH analysis of samples, PAH samples must be protected against oxidation and photoirradiation processes as PAHs are sensitive towards light (Skláršová et al. 2012). Hence, minimum exposure of light towards the samples during matrix pretreatment is highly encouraged. Tamakawa et al. (1992) has found that during the sample preparation to extract PAHs, three or fewer aromatic rings of PAHs (ANT, FA and PY) were found to be sublimated easily during the 
concentration processes. Therefore, concentration to dryness should be monitored carefully to minimize any evaporation of PAHs and minimize losses of lower molecular weight PAHs. Internal standards or surrogates are being advised to be added to the samples before extraction to ensure precise and accurate quantification by analytical instruments (Guillen et al. 2000a, 2000b, 2000c).

\section{Extraction}

Various extraction methods have been proposed and validated by researchers globally; however, only successful and effective extraction procedures are integrated into the experiments to ensure that samples have minimum analytical interferences. Alkaline saponification/solvent extraction using ethanolic $\mathrm{KOH}, \mathrm{NaOH}$, and methanolic solution is the most common method used for the removal of fats, pigments, and other organic contaminants to avoid any interference during the analysis (Tatatsuki et al. 1985; Girelli et al. 2017). Certain PAHs can easily undergo chemical, physical, and biological change or breakdown when harsh saponification conditions are applied; therefore, for food samples that have low content of fat, liquid-liquid extraction (LLE) can be applied (Tatatsuki et al. 1985). Newer methods such as the QuEChERS method (abbreviated from quick, easy, cheap, effective, rugged, and safe) (Pincemaille et al. 2014) and dispersive liquid-liquid microextraction (dllMe) (Rivera-Vera et al. 2019) have been developed and diligently used by scientists for the determination of PAHs. In addition, the two newer methods mentioned above are more cost efficiency and safer as less solvent will be consumed during the process of extraction (Zelinkova and Wenzl 2015; Purcaro et al. 2013).

Other methods for PAH extraction in beverages are pressurized liquid extraction (PLE) (Ziegenhals et al. 2008), ultrasound-assisted extraction (UAE) (Guatemala-Morales et al. 2016), solid-phase extraction (SPE) (Caruso and Alaburda 2009), Soxhlet extraction (Grover et al. 2013), solid-phase microextraction (SPME) (Viñas et al. 2007), stir bar sorptive extraction (SBSE) (Zuin et al. 2005), membrane-assisted solvent extraction (MASE) (Mañana-López, et al. 2021), microwave-assisted extraction (MAE) (Kamalabadi et al. 2018), and magnetic solid-phase extraction (MSPE) (Shariatifar et al. 2020). However, due to the challenging matrices present, inconsistent recoveries are often obtained and therefore causing an interference to the peaks in the chromatograms. The advantages and disadvantages of each method mentioned above are summarized in Table 1.

For tea samples, the commonly used method for extracting PAHs from the matrix is QuEChERS (Sadowska-Rociek et al. 2014; Tfouni et al. 2018). Recently, modern analytical chemistry strives to develop and integrate green chemistry into their research in which there is reduced usage of samples and solvents, which also employ easy procedures, simple analytical equipment, and reagents that are not harmful to individual health and the environment (Sadowska-Rociek et al. 2014). One of them is QuEChERS which was initially developed for the analysis of pesticide residues in food samples of plant origin (Anastassiades et al. 2003). On the other hand, coffee samples were conventionally extracted by saponification (Lee and Shin 2010). This is because coffee contains around $15 \%$ lipids which can cause interference during the analysis of PAHs (Houessou et al. 2006); hence, saponification using ethanolic $\mathrm{KOH}, \mathrm{NaOH}$, and methanolic solution is an effective method used for lipid removal. Alkaline saponification followed by LLE is also commonly done to remove fatty acids present in the matrix (Lee and Shin 2010). Chung et al. (2010) and Naccari et al. (2011) have applied saponification to extract PAHs from milk samples. This is due to the fact that PAHs are lipophilic and have a huge tendency to be distributed in milk (Zhao et al. 2017, 2018). According to literature, various methods ranging from LLE, SPE, SPME, QuEChERS, UAE, and DLLME were used to extract PAHs from alcoholic beverages (Will et al. 2018). The LLE and SPE were the preferred methods many years ago, but in recent years, SPME, DLLME, and QuEChERS methods were used as analytical extraction methods for alcoholic beverages (Galinaro et al. 2007; Da Silva et al. 2019).

\section{Cleanup}

The cleanup of extracts is carried out to separate target PAHs from other compounds and to remove any interferences that can make the determination of PAHs challenging. Various cleanup methods such as column chromatography, SPE, gel permeation chromatography (GPC), and thin-layer chromatography (TLC) have been studied extensively (Tamakawa 2008). Normally, large volumes of hazardous solvents need to be used to purify the PAHs because they have lipophilic properties and their extraction is correlated with lipid constituents of food (Purcaro et al. 2013).

On the other hand, commercial SPE cartridges have substituted conventional chromatographic methods and are widely used as the cleanup step for the purification of PAHs in water samples (Kouzayha et al. 2011), food (Bishnoi et al. 2005), and airborne particles (Tala and Chantara 2019), due to their multiple advantages such as higher recoveries obtained, less time consumption, and reduced usage of hazardous solvents (Sibiya et al. 2012). Additionally, SPE is excellent not only for sample cleanup, but also for sample extraction and concentration (Sibiya et al. 2012). 


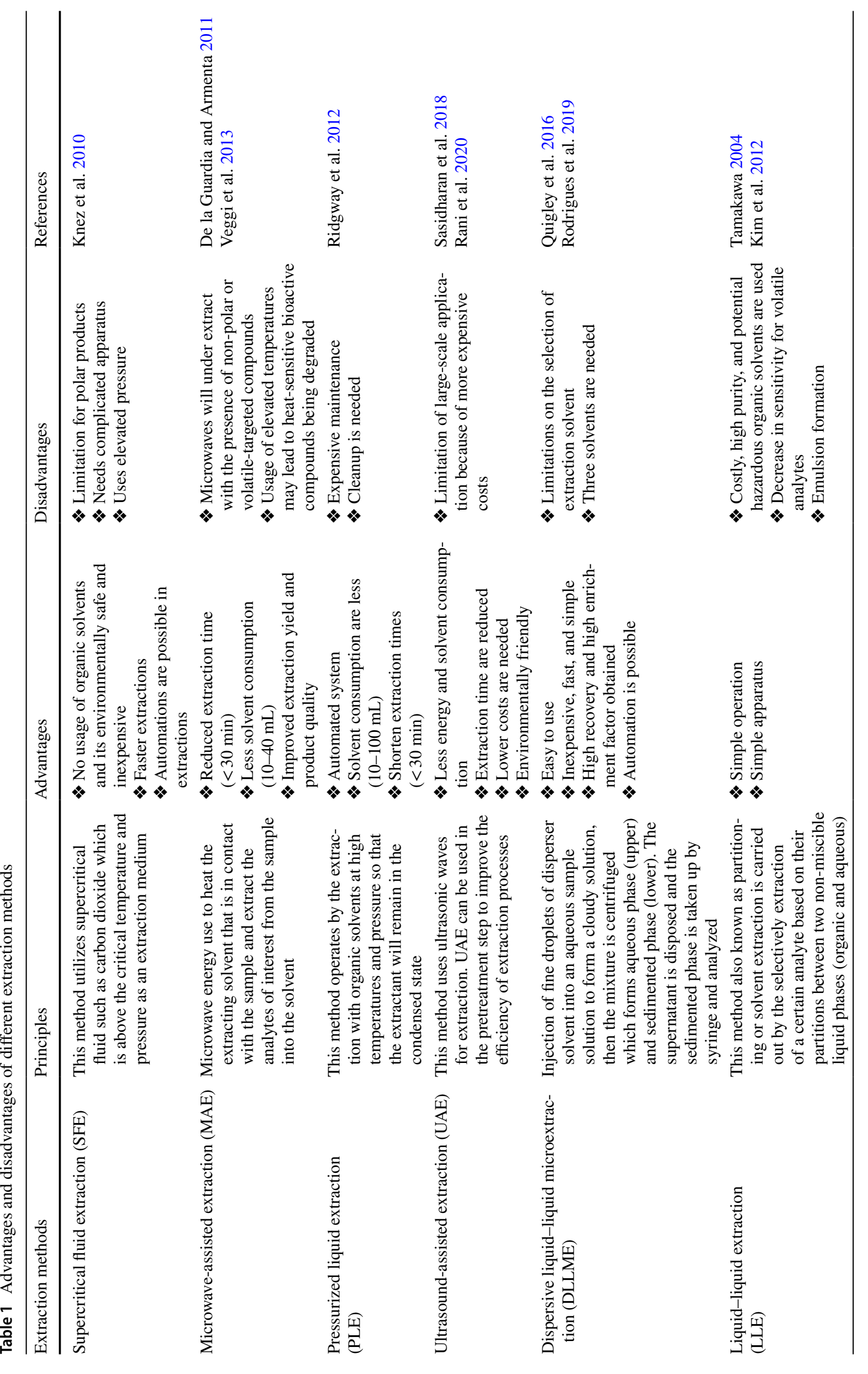




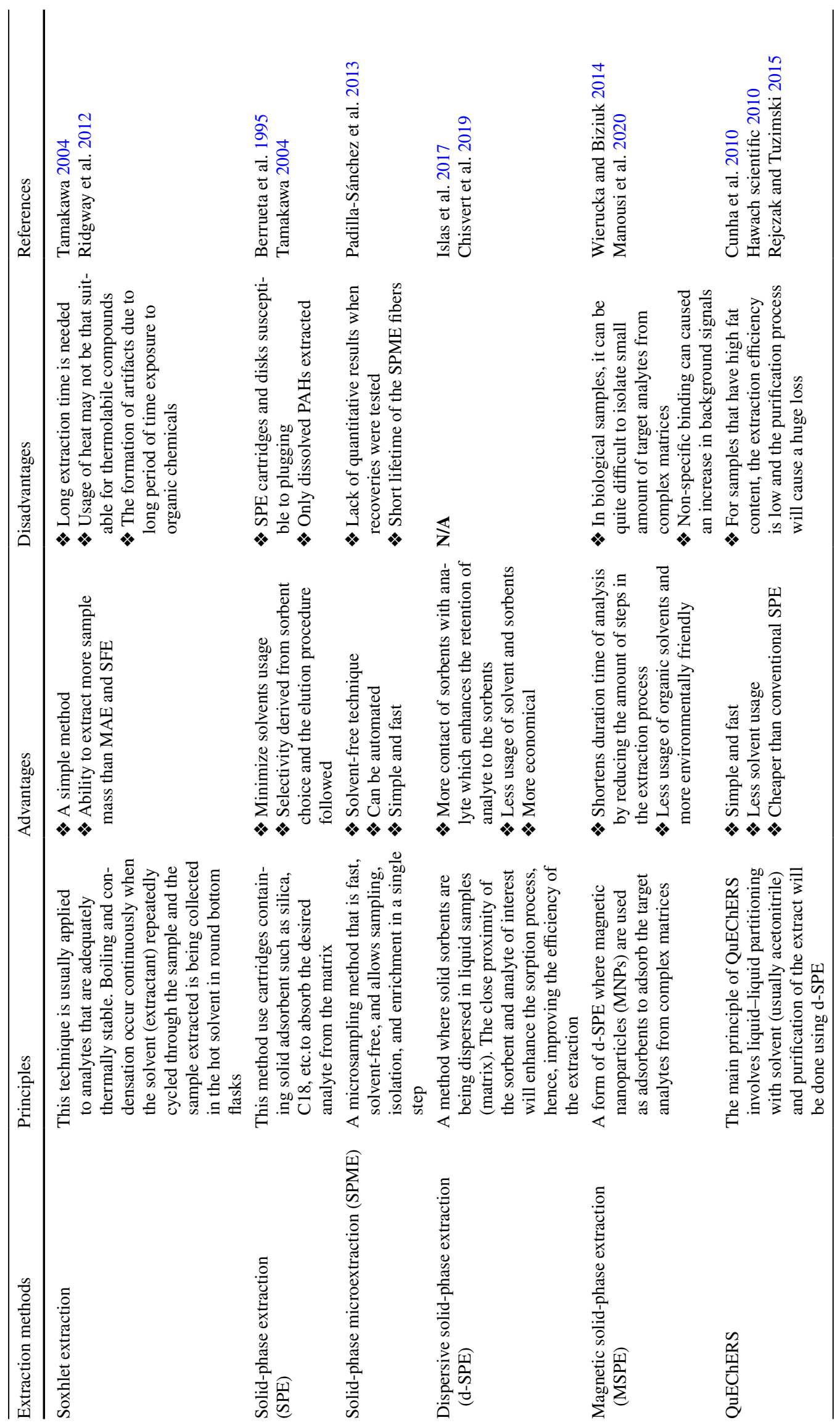




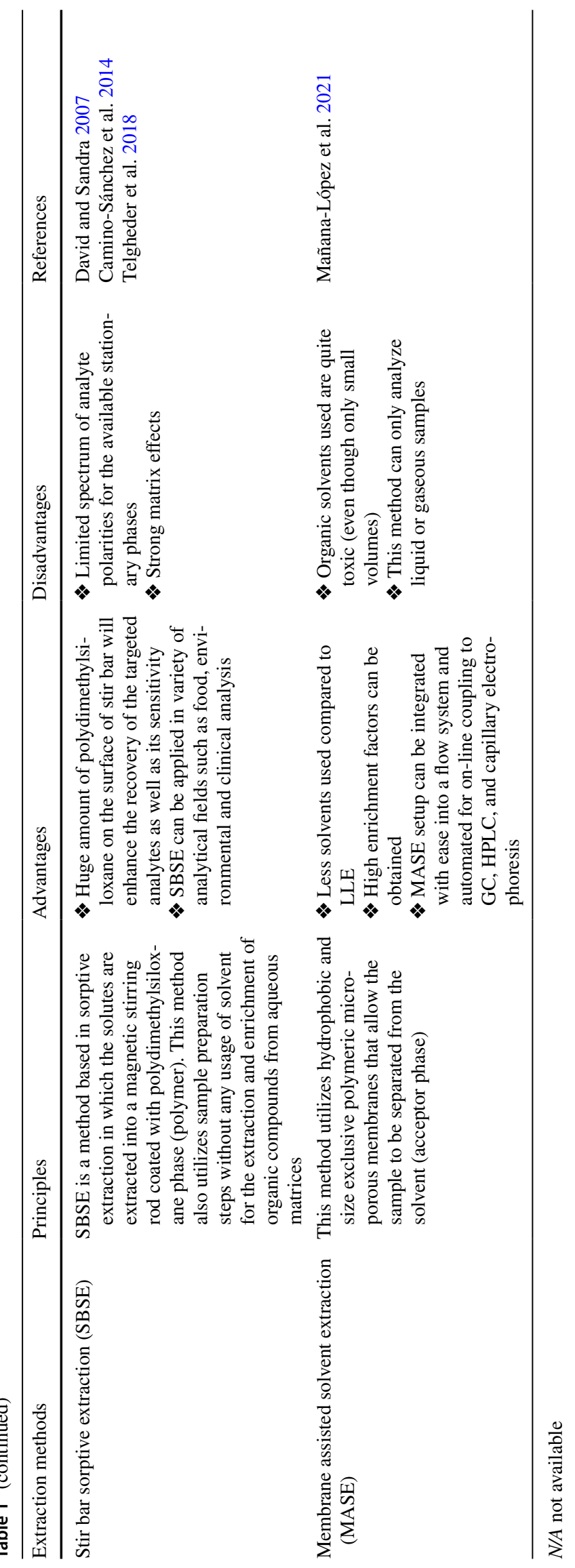




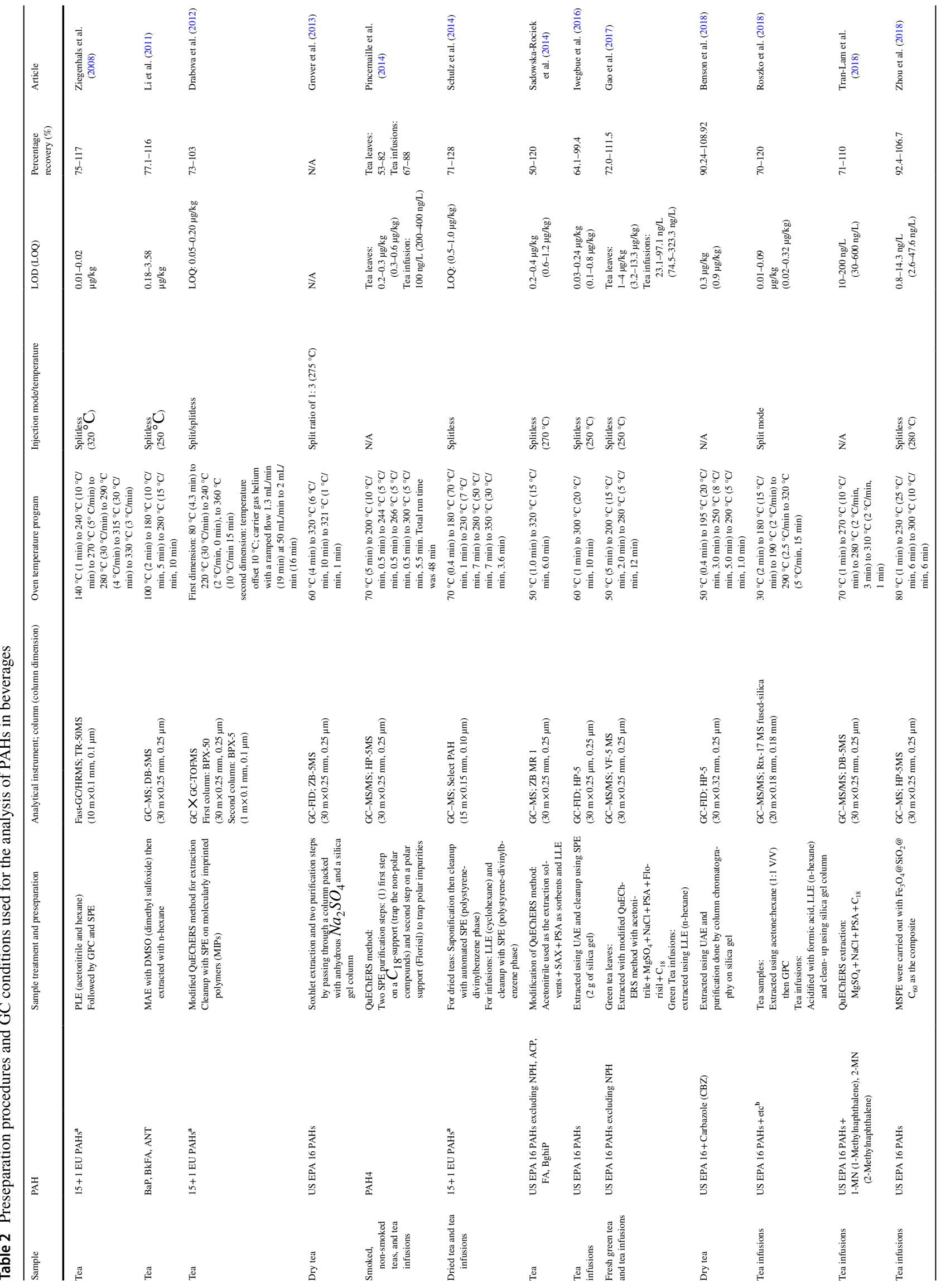




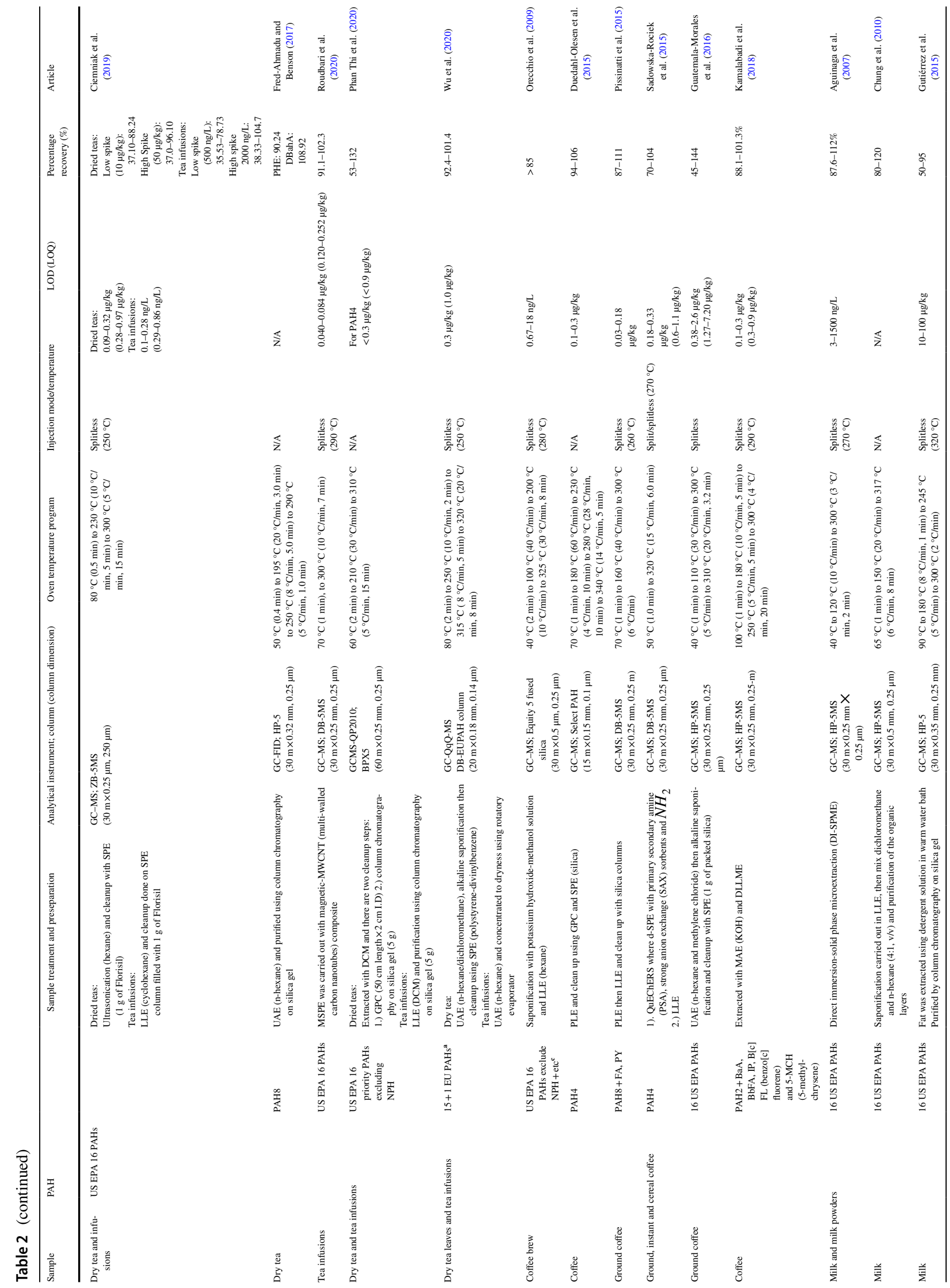




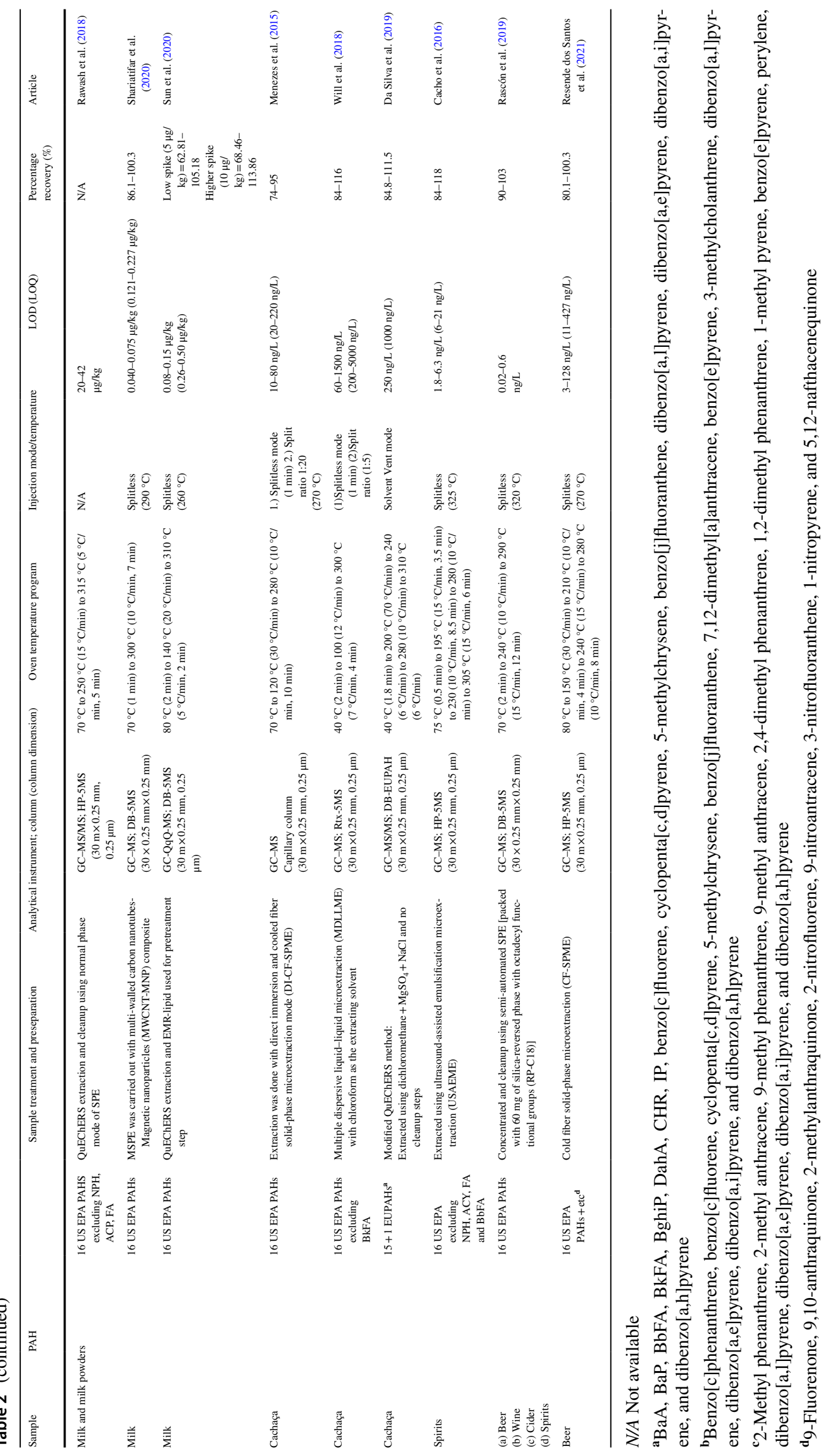




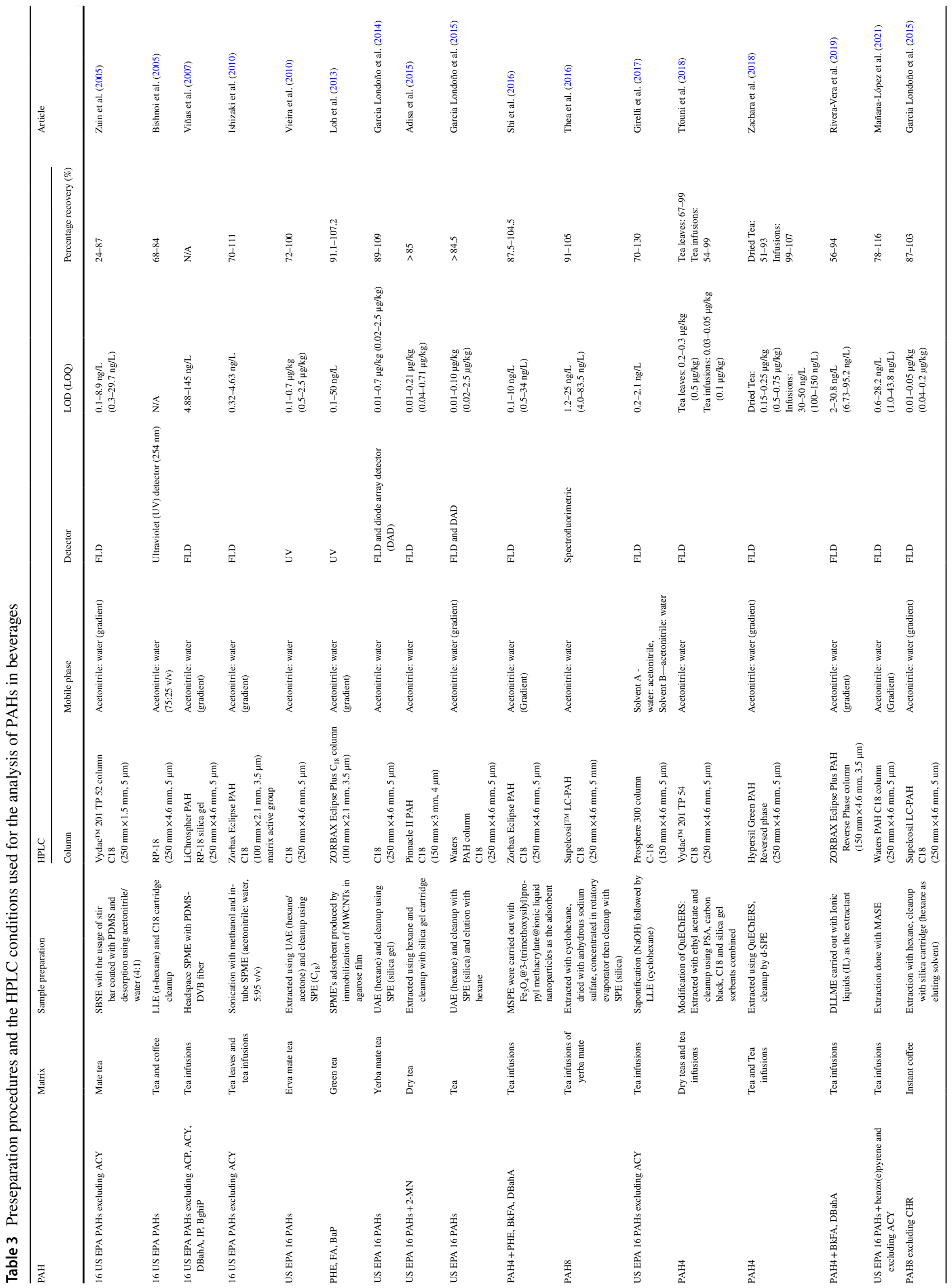




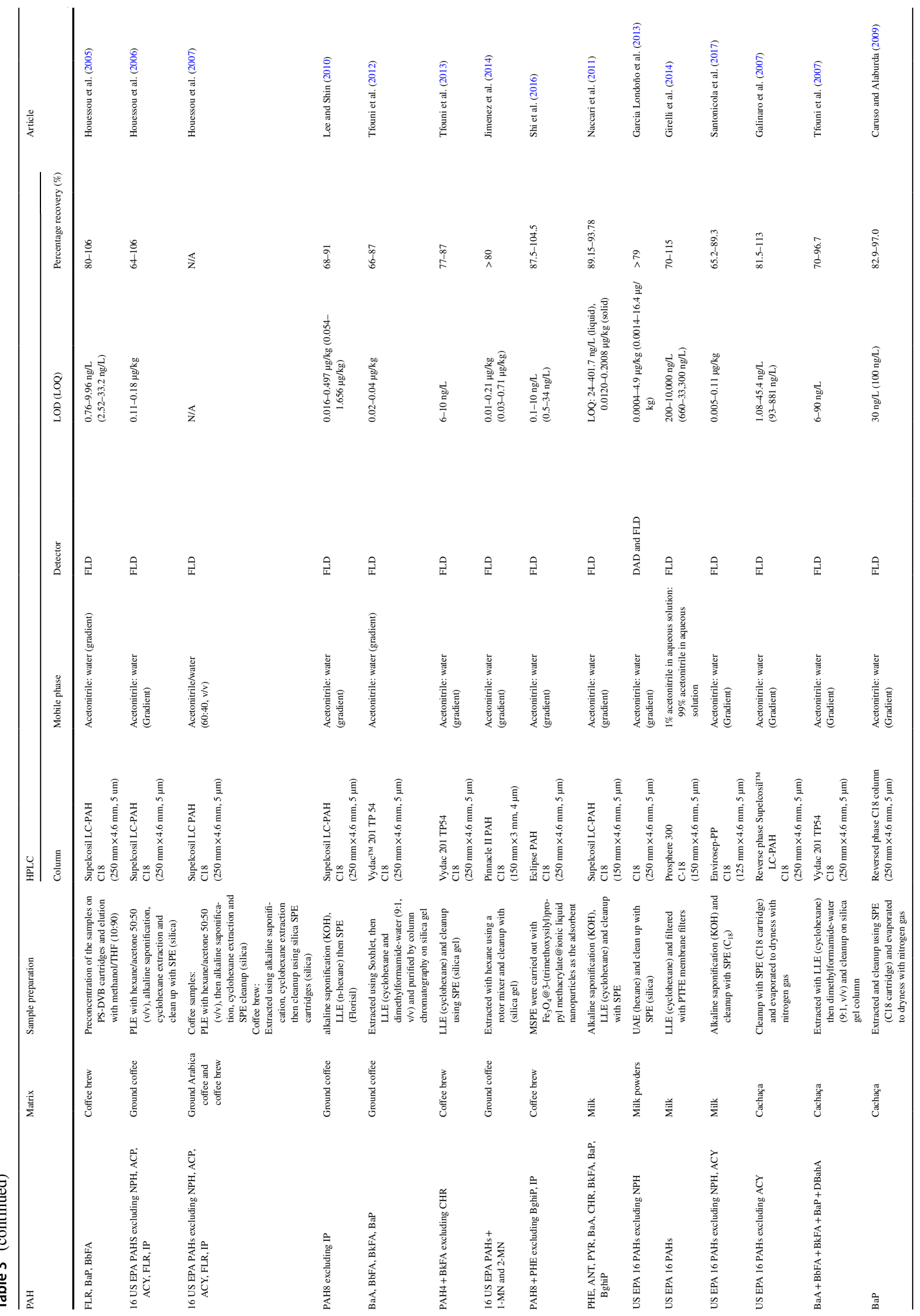




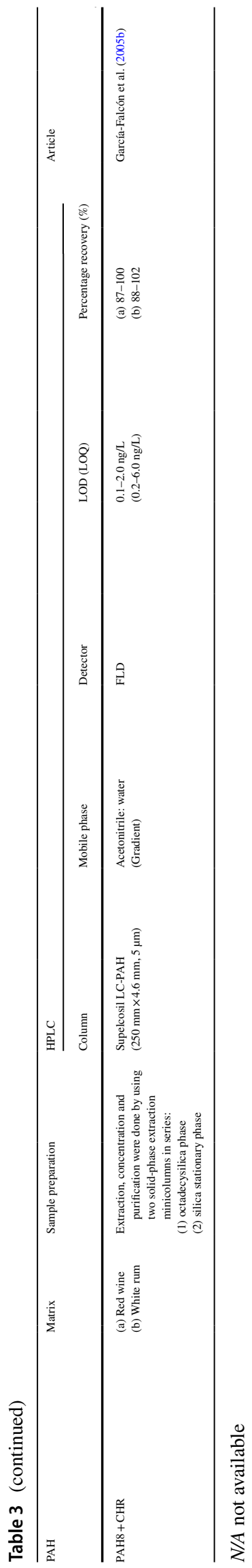

\section{Analysis}

To determine the quantity of PAHs in beverages, chromatographic analysis methods using analytical instruments are most commonly employed, such as liquid chromatography (LC) coupled with a fluorescence detector (FLD) (KayaliSayadi et al. 2000) and gas chromatography coupled with mass spectrometry (GC-MS) (Purcaro et al. 2007; Schulz et al. 2014; Zhou et al. 2018; Sun et al. 2020).

High-performance liquid chromatography with fluorescence detection (HPLC-FLD) is a highly recommended method for the routine screening purpose of PAHS due to its selectivity and sensitivity. HPLC is also preferable for the quantification of PAH isomers. For instance, the isomers chrysene/triphenylene, the first is a target PAH but the second may interfere with chrysene quantification by gas chromatography (GC) (Zelinkova and Wenzl 2015). Therefore, HPLC should be selected for this analysis as GC is unable to resolve some pairs of peaks.

GC-MS is a widely acclaimed analytical instrument for the analysis of PAHs in food samples, and researchers have been extensively employing GC-MS in their studies. This is because $\mathrm{GC}$ has a better resolution efficiency compared to HPLC (Tamakawa 2008) and MS provides high selectivity and sensitivity as well as structural information of PAHs (Plaza-bolaños et al. 2010). GC-MS allows the resolution of PAHs with poor fluorescence, such as NPH, ACY, ACP, and FLR or non-fluorescence PAHs, such as cyclopenta(c,d)pyrene (CPcdP) (Cai et al. 2009). Furthermore, gas chromatography-tandem mass spectrometry (GC-MS/MS) detection is a widely popular method which presents high sensitivity and resolution (Plaza-bolaños et al. 2010).

Based on literature reviews, PAHs in beverages were most frequently analyzed by GC-MS in selected ion monitoring (SIM) mode, where only masses of PAHs of interested are monitored. The limits of detections (LODs), limits of quantifications (LOQs), and percent recoveries for the analysis of beverages using GC-MS and HPLC gathered from different literatures are summarized as shown in Table 2 and Table 3, respectively. For the separation of compounds in complex food samples including beverages, two types of columns that are commonly used in GC analysis are DB-5MS column coated with 5\%-phenyl-Arylene-95\%-dimethylpolysiloxane (Sadowska-Rociek et al. 2015; Roudbari et al. 2020) and HP-5MS column coated with 5\%-phenyl-95\%-dimethylpolysiloxane (Aguinaga et al. 2007; Zhou et al. 2018). Whereas for the HPLC analysis, the C18 column or its equivalence, running in isocratic or gradient elution, is favorable for the analysis of PAHs in most of the reported publications as summarized in Table 3 (Garcia Londoño et al. 2015; Shi et al. 2016; Tfouni et al. 2018; Mañana-López et al. 2021). There are also an increasing number of columns which are specifically developed for the analysis PAHs using HPLC 
such as Eclipse PAH column, Supelcosil ${ }^{\mathrm{TM}}$ LC PAH column, Hypersil Green PAH column, Envirosep-PP, Pinnacle II PAH, Vydac ${ }^{\mathrm{TM}}$ and LiChrospher PAH column to name a few (Shi et al. 2016; Thea et al. 2016; Kayali-Sayadi et al. 1999; Santonicola et al. 2017; Adisa et al. 2015; Zuin et al. 2005; Viñas et al. 2007). This indicates the growing importance of the analysis of PAHs.

According to Table 2 and Table 3, it was observed that different results of LODs, LOQs, and recoveries were obtained when different sample extraction methods, cleanup, and instrumental analysis were employed. The lowest LODs obtained using GC-MS for the analysis of tea, tea infusions, ground coffee, coffee brew, milk, and alcoholic beverages were $0.01-0.02 \mu \mathrm{g} / \mathrm{kg}, 0.1-0.28 \mathrm{ng} / \mathrm{L}, 0.03-0.18 \mu \mathrm{g} / \mathrm{kg}$, $0.67-18 \mathrm{ng} / \mathrm{L}, 3-1500 \mathrm{ng} / \mathrm{L}$, and $0.02-0.6 \mathrm{ng} / \mathrm{L}$ respectively. For HPLC, the lowest LODs reported for tea, tea infusions, ground coffee, coffee brew, milk, and alcoholic beverages were $0.32-4.63 \mathrm{ng} / \mathrm{L}, 0.2-2.1 \mathrm{ng} / \mathrm{L}, 0.01-0.21 \mu \mathrm{g} /$ $\mathrm{kg}, 0.1-10 \mathrm{ng} / \mathrm{L}, 0.0004-4.9 \mu \mathrm{g} / \mathrm{kg}$, and $0.1-2.0 \mathrm{ng} / \mathrm{L}$ respectively. Lower LODs in beverages were observed with the usage of HPLC compared to GC. In addition, percentage recoveries were mostly within the range of $70-110 \%$ for beverages analyzed using GC and HPLC.

\section{Conclusion}

Global concerns have been raised due to the discovery of increasing amounts of PAHs found in beverages, prompting researches to develop sample extraction and analytical methods for the determination of PAHs in the past 16 years. Extraction methods with the usage of green extractants to minimize hazardous organic solvents wastage to the environment are being developed as well as integrated into existing research, and have been used extensively due to their simplicity. Analytical instruments, in particular GC and HPLC with detectors such as MS, MS/MS, FID and FLD are generally favored for the analysis of PAHs; LOD as low as 0.02 ppt level can be accomplished. It was found that QuEChERS is a popular method for the extraction of PAHs from tea, whereas saponification is more commonly used for the extraction of PAHs from both coffee and milk. For alcoholic beverages, LLE, SPE and microextraction techniques are commonly used.

Acknowledgements The authors would like to express gratitude to the Ministry of Education (MOE), Brunei Darussalam, and Universiti Brunei Darussalam (UBD) for granting scholarship and research facilities to the graduate student.

No studies of conducting experiments on animals performed by any of the two authors in this article.

\section{Declarations}

Informed Consent Not applicable.

Conflict of Interest Peng Pau Lian declares that she has no conflict of interest. Lee Hoon Lim declares that she has no conflict of interest.

Open Access This article is licensed under a Creative Commons Attribution 4.0 International License, which permits use, sharing, adaptation, distribution and reproduction in any medium or format, as long as you give appropriate credit to the original author(s) and the source, provide a link to the Creative Commons licence, and indicate if changes were made. The images or other third party material in this article are included in the article's Creative Commons licence, unless indicated otherwise in a credit line to the material. If material is not included in the article's Creative Commons licence and your intended use is not permitted by statutory regulation or exceeds the permitted use, you will need to obtain permission directly from the copyright holder. To view a copy of this licence, visit http://creativecommons.org/licenses/by/4.0/.

\section{References}

Abddel-Shafy HI, Mansour MSM (2016) A review on polycyclic aromatic hydrocarbons: source, environmental impact, effect on human health and remediation. Egypt J Pet 25(1):107-123

Adisa A, Jimenez A, Woodham C, Anthony K, Nguyen T, Saleh MA (2015) Determination of polycyclic aromatic hydrocarbons in dry tea. J Environ Sci Heal Part B Pestic Food Contam Agric Wastes 50(8):552-559

Agency for Toxic Substances and Disease Registry (ATSDR) (2009a) What health effects are associated with PAH exposure https:// www.atsdr.cdc.gov/csem/polycyclic-aromatic-hydrocarbons/ health_effects.html

Agency for Toxic Substances and Disease Registry (ATSDR) (2009b) What are the standards and regulations for PAHs exposure? https://www.atsdr.cdc.gov/csem/polycyclic-aromatic-hydrocarbo ns/standards_and_regulations_for_exposure.html

Aguinaga N, Campillo N, Viñas P, Hernández-Córdoba M (2007) Determination of 16 polycyclic aromatic hydrocarbons in milk and related products using solid-phase microextraction coupled to gas chromatography-mass spectrometry. Anal Chim Acta 596(2):285-290

Aguinaga N, Campillo N, Viñas P, Hernández-Córdoba M (2008) A headspace solid-phase microextraction procedure coupled with gas chromatography-mass spectrometry for the analysis of volatile polycyclic aromatic hydrcarbons in milk samples. Anal Bioanal Chem 391:753-758

Alexander J, Benford D, Cockburn A, Cravedi J, Dogliotti E, Domenico ADi, Fernández-cruz ML, Fink-gremmels J, Fürst P, Galli C (2008) Polycyclic aromatic hydrocarbons in food - scientific opinion of the panel on contaminants in the food chain. EFSA J 6(8):1-114

Anastassiades M, Lehotay SJ, Stajnbaher D, Schenck FJ (2003) Fast and easy multiresidue method employing acetonitrile extraction/ partitioning and dispersive solid-phase extraction for the determination of pesticide residues in produce. J AOAC Int 86:412-431

Anderson HE, Santos IC, Hildenbrand ZL, Schug KA (2019) A review of the analytical methods used for beer ingredient and finished product analysis and quality control. Anal Chim Acta 1085:1-20

Aygun SF, Bagcevan B (2020) Determination of polycyclic aromatic hydrocarbons (PAHs) in drinking water of Samsun and it's surrounding areas, Turkey. J Environ Heal Sci Eng 17(2):1205-1212 
Benson NU, Fred-Ahmadu OH, Olugbuyiro JAO, Anake WU, Adedapo AE, Olajire AA (2018) Concentrations, sources and risk characterisation of polycyclic aromatic hydrocarbons (PAHs) in green, herbal and black tea products in Nigeria. J Food Compos Anal 66:13-22

Berrueta LA, Gallo B, Vicente F (1995) A review of solid phase extraction: basic principles and new developments. Chromatographia 40:474-483

Bishnoi NR, Mehta U, Sain U, Pandit GG (2005) Quantification of polycyclic aromatic hydrocarbons in tea and coffee samples of Mumbai City (India) by high performance liquid chromatography. Environ Monit Assess 107(1-3):399-406

Cacho JI, Campillo N, Viñas P, Hernández-Córdoba M (2016) Evaluation of the contamination of spirits by polycyclic aromatic hydrocarbons using ultrasound-assisted emulsification microextraction coupled to gas chromatography-mass spectrometry. Food Chem 190:324-330

Cai SS, Syage JA, Hanold KA, Balogh MP (2009) Ultra performance liquid chromatography-atmospheric pressure photoionizationtandem mass spectrometry for high-sensitivity and high-throughput analysis of U.S. Environmental Protection Agency 16 priority pollutants polynuclear aromatic hydrocarbons. Anal Chem 81(6):2123-8. https://doi.org/10.1021/ac802275e

Camino-Sánchez FJ, Rodríguez-Gómez R, Zafra-Gómez A, SantosFandila A, Vílchez JL (2014) Stir bar sorptive extraction: recent applications, limitations and future trends. Talanta 130:388-399

Cardoso DR, Andrade-Sobrinho LG, Leite-Neto AF, Reche RV, Isique WD, Ferreira MMC (2004) Comparison between Cachaça and rum using pattern recognition methods. J Agric Food Chem 52(11):3429-3433

Caruso MSF, Alaburda J (2009) Optimization of the benzo(A)pyrene determination procedure in cachaça. J Braz Chem Soc 20(3)

Chen BH, Chen YC (2001) Formation of polycyclic aromatic hydrocarbons in the smoke from heated model lipids and food lipids. J Agric Food Chem 49:5238-5243

Chinnici F, Natali N, Spinabelli U, Riponi C (2007) Presence of polycyclic aromatic hydrocarbons in woody chips used as adjuvant in wines, vinegars and distillates. LWT Food Sci Technol 40:1587-1592

Chisvert A, Cárdenas S, Lucena R (2019) Dispersive micro-solid phase extraction. TrAC 112:226-233

Chung TL, Liao CJ, Chen MF (2010) Comparison of liquid-liquid extraction and solid-phase extraction for the determination of polycyclic aromatic hydrocarbons in the milk of Taiwan. J Taiwan Inst Chem Eng 41(2):178-183

Ciemniak A, Kuźmicz K, Rajkowska-Myśliwiec M, Cadena MF (2019) Assessing the contamination levels of dried teas and their infusions by polycyclic aromatic hydrocarbons (PAHs). J Fur Verbraucherschutz Und Leb 14(3):263-274

Codex Alimentarius Commission (CX/FAC 06/38/36) (2005). Joint FAO/WHO food standards programme codex committee on food additives and contaminants. Discussion paper on polycyclic aromatic hydrocarbons (PAH) contamination.

Cunha SC, Lehotay SJ, Mastovska K, Fernandes JO, Oliveira MBPP (2010) Sample preparation approaches for the analysis of pesticide residues in olives and olive oils. In: Preedy VR, Watson $\mathrm{RR}$ (eds) Olives and olive oil in health and disease prevention. Academic Press, Amsterdam, p 655

Da Porto C, Moret S, Soldera S (2006) A study on the composition of distillates obtained from smoked marc. Anal Chim Acta 563:396-400

Da Silva MC, Oliveira MLG, Augusti R, Faria AF (2019) Simultaneous extraction of pesticides and polycyclic aromatic hydrocarbons in Brazilian Cachaça using a modified QuEChERS method followed by gas chromatography coupled to tandem mass spectrometry quantification. J Agric Food Chem 67(1):399-405
David F, Sandra P (2007) Stir bar sorptive extraction for trace analysis. J Chromatogr A 1152(1-2):54-69

De la Guardia M, Armenta S (2011) Greening sample treatments Comprehensive analytical chemistry. Elsevier, Amsterdam, pp 87-120

de Vos RH, van Dokkum W, Schouten A, de Jong-Berkhout P (1990) Polycyclic Aromatic hydrocarbons in Dutch total diet samples (1984-1986). Food Chem Toxicol 28(4):263-268

Dimanshki M, Lim LH, Harrison RM, Harrad S (2001) Temporal trends, temperature dependence, and relative reactivity of atmospheric polycyclic aromatic hydrocarbons. Environ Sci Technol 35(11):2264-2267

Drabova L, Pulkrabova J, Kalachova K, Tomaniova M, Kocourek V, Hajslova J (2012) Rapid determination of polycyclic aromatic hydrocarbons (PAHs) in tea using two-dimensional Gas chromatography coupled with time of flight mass spectrometry. Talanta 100:207-216

Duedahl-Olesen L, Navaratnam MA, Jewula J, Jensen AH (2015) PAH in some brands of tea and coffee. Polycycl Aromat Compd 35(1):74-90

US EPA (2018) 2018 Edition of the Drinking Water Standards and Health Advisories Tables. https://www.epa.gov/sites/production/ files/2018-03/documents/dwtable2018.pdf

Essumang DK, Dodoo DK, Adjei JK (2013) Effect of smoke generation sources and smoke curing duration on the levels of polycyclic aromatic hydrocarbon (PAH) in different suites of fish. Food Chem Toxicol 58:86-94

European Commission, Health and Consumer Protection DirectorateGeneral, Scientific Committee on Food (2002) Opinion of the scientific committee on food on the risk to human health of polycyclic aromatic hydrocarbons -occurrence in food SCF/CS/ CNTM/ PAH/29.

Food and Agriculture Organization of the United Nations (FAO) (2012). Firm tea prices set to continue. http://www.fao.org/news/ story/en/item/124221/icode/

Food and Agriculture Organization of the United Nations (FAO) (2015) Crop production quantities by country: average 1993-2013. http://faostat3.fao.org/browse/Q/QC/E.

Fred-Ahmadu O, Benson N (2017) Polycyclic aromatic hydrocarbons (PAHs) occurrence and toxicity in Camellia sinensis and herbal tea. Polycyclic Aromat Compd 39:1-11

Galinaro CA, Cardoso DR, Franco DW (2007) Profiles of polycyclic aromatic hydrocarbons in Brazilian sugar cane spirits: discrimination between Cachaças produced from nonburned and burned sugar cane crops. J Agric Food Chem 55(8):3141-3147

Gao G, Chen H, Liu P, Hao Z, Ma G, Chai Y, Wang C, Lu C (2017) Residue pattern of polycyclic aromatic hydrocarbons during green tea manufacturing and their transfer Rates during tea brewing. Food Addit Contam Part A Chem Anal Control Expo Risk Assess 34(6):990-999

Garcia Londoño VA, Garcia LP, Scussel VM, Resnik S (2013) Polycyclic aromatic hydrocarbons in milk powders marketed in Argentina and Brazil. Food Addit Contam Part A Chem Anal Control Expo Risk Assess 30(9):1573-1580

Garcia Londoño VA, Reynoso M, Resnik S (2014) Polycyclic aromatic hydrocarbons (PAHs) in yerba mate (Ilex Paraguariensis) from the Argentinean market. Food Addit Contam Part B Surveill 7(4):247-253

Garcia Londoño VA, Reynoso CM, Resnik SL (2015) Polycyclic aromatic hydrocarbons (PAHs) survey on tea (Camellia sinensis) commercialized in Argentina. Food Control 50:31-37

García-Falcón MS, Simal-Gándara J (2005a) Determination of polycyclic aromatic hydrocarbons in alcoholic drinks and the identification of their potential sources. Food Addit Contam 22:791-797

García-Falcón MS, Cancho-Grande B, Simal-Gándara J (2005b) Minimal clean-up and rapid determination of polycyclic aromatic hydrocarbons in instant coffee. Food Chem 90:643-647 
Girelli AM, Sperati D, Tarola AM (2014) Determination of polycyclic aromatic hydrocarbons in Italian milk by HPLC with fluorescence detection. Food Addit Contam Part A Chem Anal Control Expo Risk Assess 31(4):703-710

Girelli, AM, Apriceno A, Tarola A, Tortora F (2017) Determination of polycyclic aromatic hydrocarbons in tea infusions samples by high performance liquid chromatography with fluorimetric detection. J Food Quality 2017

Gope M, Masto RE, George J, Balachandran S (2018) Exposure and cancer risk assessment of polycyclic aromatic hydrocarbons (PAHs) in the street dust of Asansol city, India. Sustain Cities Soc 38:616-626

Grova N, Feidt C, Laurent C, Rychen G (2002) [14C] Milk, urine and faeces excretion kinetics in lactating goats after an oral administration of $[14 \mathrm{C}]$ polycyclic aromatic hydrocarbons. Int Dairy J 12:1025-1031

Grover IS, Singh S, Pal B (2013) Priority PAHs in orthodox black tea during manufacturing process. Environ Monit Assess 185(8):6291-6294

Guatemala-Morales GM, Beltrán-Medina EA, Murillo-Tovar MA, Ruiz-Palomino P, Corona-González RI, Arriola-Guevara E (2016) Validation of analytical conditions for determination of polycyclic aromatic hydrocarbons in roasted coffee by gas chromatography-mass spectrometry. Food Chem 197:747-753

Guillén MD, Sopelana P (2005) Headspace solid-phase microextraction as a tool to estimate the contamination of smoked cheeses by polycyclic aromatic hydrocarbons. J Dairy Sci 88(1):13-20

Guillen MD, Sopelana P, Partearroyo MA (2000a) Determination of polycyclic aromatic hydrocarbons in commercial liquid smoke flavorings of different compositions by gas chromatography-mass spectrometry. J Agric Food Chem 48:126-131

Guillen MD, Sopelana P, Partearroyo MA (2000b) Study of several aspects of a general method for the determination of polycyclic aromatic hydrocarbons in liquid smoke flavourings by gas chromatography-mass spectrometry. Food Addit Contam 17(1):27-44

Guillen MD, Sopelana P, Partearroyo MA (2000c) Polycyclic aromatic hydrocarbons in liquid smoke flavorings obtained from different types of wood, effect of storage in polyethylene flasks on their concentration. J Agric Food Chem 48:5083-5087

Gul O, Dervisoglu M, Mortas M, Aydemir O, Ilhan E, Aksehir K (2015) Evaluation of polycyclic aromatic hydrocarbons in Circassian cheese by high-performance liquid chromatography with fluorescence detection. J Food Compos Anal 37:82-86

Gutiérrez R, Vega S, Ortiz R, Pérez JJ, Schettino B (2015) Presence of PAHs in milk of industrial farms from Tizayuca, Hidalgo, Mexico. J Environ Sci Heal Part B Pestic Food Contam Agric Wastes 50(5):317-321

Herbstman JB, Tang D, Zhu D, Qu L, Sjödin A, Li Z, Camann D, Perera FP (2012) Prenatal exposure to polycyclic aromatic hydrocarbons, benzo[a]pyrene-DNA adducts, and genomic DNA methylation in cord blood. Environ Health Perspect 120(5):733-773

Höner A (2001) Polycyclic aromatic hydrocarbon (PAH) metabolites. In: Kleiböhmer W (ed) Handbook of Analytical Separations. Elsevier, Berlin, pp 99-121

Houessou JK, Benac C, Delteil C, Camel V (2005) Determination of polycyclic aromatic hydrocarbons in coffee brew using solidphase extraction. J Agric Food Chem 53(4):871-879

Houessou JK, Delteil C, Camel V (2006) Investigation of sample treatment steps for the analysis of polycyclic aromatic hydrocarbons in ground coffee. J Agric Food Chem 54(20):7413-7421

Houessou JK, Maloug S, Leveque AS, Delteil C, Heyd B, Camel V (2007) Effect of roasting conditions on the polycyclic aromatic hydrocarbon content in ground arabica coffee and coffee brew. J Agric Food Chem 55(23):9719-9726

Houessou JK, Goujot D, Heyd B, Camel V (2008) Modeling the formation of some polycyclic aromatic hydrocarbons during the roasting of arabica coffee samples. J Agric Food Chem 56(10):3648-3656

Huang M, Penning TM (2014) Polycyclic aromatic hydrocarbons (PAHs). In: Mortarjemi Y, Moy G, Todd E (eds) Encyclopedia of Food Safety. Academic press, Cambridge, pp 416-423

Ishizaki A, Saito K, Hanioka N, Narimatsu S, Kataoka H (2010) Determination of polycyclic aromatic hydrocarbons in food samples by automated on-line in-tube solid-phase microextraction coupled with high-performance liquid chromatography-fluorescence detection. J Chromatogr A 1217(35):5555-5563

Islas G, Ibarra IS, Hernandez P, Miranda JM, Cepeda A (2017) Dispersive solid phase extraction for the analysis of veterinary drugs applied to food samples: a review. Int J Anal Chem 2017

Iwegbue CMA, Tesi GO, Bassey FI, Martincigh BS, Nwajei GE, Ucheaga C (2016) Determination of polycyclic aromatic hydrocarbons in water- and gin-based tea infusions of selected tea brands in Nigeria. Polycycl Aromat Compd 36(4):564-586

Jánská M, Hajslová J, Tomaniová M, Kocourek V, Vávrová M (2006) Polycylic aromatic hydrocarbons in fruits and vegetables grown in the Czech Republic. Environ Contam Toxicol 77:492-499

Jia J, Bi C, Zhang J, Jin X, Chen Z (2018) Characterization of polycyclic aromatic hydrocarbons (PAHs) in vegetables near industrial areas of Shanghai, China: Sources, exposure, and cancer risk. Environ Pollut 241:750-758

Jimenez A, Adisa A, Woodham C, Saleh M (2014) Determination of polycyclic aromatic hydrocarbons in roasted coffee. J Environ Sci Health Part B Pestic Food Contam Agric Wastes 49(11):828-835

Jira W, Ziegenhals K, Speer K (2008) Gas chromatography-mass spectrometry (GC-MS) method for the determination of 16 European priority polycyclic aromatic hydrocarbons in smoked meat products and edible oils. Food Addit Contam Part A Chem Anal Control Expo Risk Assess 25(6):704-13

Kamalabadi M, Mohammadi A, Alizadeh N (2018) Simultaneous determination of seven polycyclic aromatic hydrocarbons in coffee samples using effective microwave-assisted extraction and microextraction method followed by gas chromatography-mass spectrometry and method optimization using central composit. Food Anal Methods 11(3):781-789

Kayali-Sayadi MN, Rubio-Barroso S, Cuesta-Jimenez MP, Polo-Díez LMA (1999) New method for the determination of selected PAHs in coffee brew samples by HPLC with fluorimetric detection and solid-phase extraction. J Liq Chromatogr Relat Technol 22(4):615-627

Kayali-Sayadi MN, Rubio-Barroso S, Díaz-Díaz CA, Polo-Díez LM (2000) Rapid determination of PAHs in soil samples by HPLC with fluorimetric detection following sonication extraction. Fresenius J Anal Chem 368(7):697-701

Killian E, Smith C, Jones KC (2000) Particles and vegetation: implications for the transfer of particle-bound organic contaminants to vegetation. Sci Total Environ 246:207-236

Kim J, Choi K, Chung DS (2012) 3.35- Sample preparation for capillary electrophoretic applications. In: Pawliszyn J (ed) Comprehensive sampling and sample preparation. Academic press, Cambridge, pp 701-721

Knez Ž, Škerget M, KnezHrnčič M (2010) Principles of supercritical fluid extraction and applications in the food, beverage and nutraceutical industries. In: Rizvi SSH (ed) Separation, extraction and concentration processes in the food, beverage and nutraceutical industries. Woodhead publishing, Oxford, pp 3-38

Kouzayha A, Al Iskandarani M, Mokh S, Rabaa AR, Budzinski H, Jaber F (2011) Optimization of a solid-phase extraction method using centrifugation for the determination of 16 polycyclic aromatic hydrocarbons in water. J Agric Food Chem 59(14):7592-7600

Kuroda Y, Hara Y (1999) Antimutagenic and anticarcinogenic activity of tea polyphenols. Mutat Res 436:69-97 
Lammel G, Klánová J, Ilić P, Kohoutek J, Gasić B, Kovacić I, Lakić N, Radić R (2010) Polycyclic aromatic hydrocarbons in air on small spatial and temporal scales - I. Levels and variabilities. Atmos Environ 44 (38):5015-5021(4):643-647

Ledesma E, Rendueles M, Díaz M (2014) Benzo (a) pyrene penetration on a smoked meat product during smoking time. Food Addit Contam Part A 31(10):1688-1698

Lee K, Shin HS (2010) Determination of polycyclic aromatic hydrocarbons in commercial roasted coffee beans. Food Sci Biotechnol 19(6): 1435-1440

Li XY, Li N, Luo HD, Lin LR, Zou ZX, Jia YZ, Li YQ (2011) A novel synchronous fluorescence spectroscopic approach for the rapid determination of three polycyclic aromatic hydrocarbons in tea with simple microwave-assisted pretreatment of sample. J Agric Food Chem 59(11):5899-5905

Lin D, Tu Y, Zhu L (2005) Concentrations and health risk of PAHs in tea. Food Chem Toxicol 43:41-48

Loh SH, Sanagi MM, Wan Ibrahim WA, Hasan MN (2013) Multiwalled carbon nanotube-impregnated agarose film microextraction of polycyclic aromatic hydrocarbons in green tea beverage. Talanta 106:200-205

Lorenzi D, Entwistle JA, Cave M, Dean JR (2011) Determination of polycyclic aromatic hydrocarbons in urban street dust: implications for human health. Chemosphere 83(7):970-977

Lund M, Duedahl-Olesen L, Christensen JH (2009) Extraction of polycyclic aromatic hydrocarbons from smoked fish using pressurized liquid extraction with integrated fat removal. Talanta 79(1):10-15

Mahugija JAM, Njale E (2018) Levels of polycyclic aromatic hydrocarbons (PAHs) in smoked and sun-dried fish samples from areas in Lake Victoria in Mwanza, Tanzania. J Food Compos Anal 73:39-46

Mañana-López A, Sánchez-Piñero J, Moreda-Piñeiro J, Turnes-Carou I, Muniategui-Lorenzo S, López-Mahía P (2021) Polycyclic aromatic hydrocarbons analysis in tea infusions and tea beverages using membrane assisted solvent extraction. Microchem J 167

Manousi N, Rosenberg E, Deliyanni E, Zachariadis GA, Samanidou V (2020) Magnetic solid-phase extraction of organic compounds based on graphene oxide nanocomposites. Molecules 25(5):1148

Menezes HC, Paulo Menezes HC, Paulo BP, Paiva MJN, de Barcelos SMR, Macedo DFD, Cardeal ZL (2015) Determination of polycyclic aromatic hydrocarbons in artisanal Cachaça by DI-CFSPME-GC/MS. Microchem J 118:272-277

Menzie CA, Potocki BB, Santodonato J (1992) Exposure to carcinogenic PAHs in the environment. Environ Sci Technol 26:1278-1284

Naccari C, Cristani M, Giofrè F, Ferrante M, Siracusa L, Trombetta D (2011) PAHs Concentration in heat-treated milk samples. Food Res Int 44(3):716-724

Nielen MWF, Marvin HJP (2008) Challenges in chemical food contaminants and residue analysis. In: Picó Y (ed) Food contaminants and residue analysis, 1st edn. Elsevier, Amsterdam, pp 2-6

Orecchio S, Ciotti VP, Culotta L (2009) Polycyclic aromatic hydrocarbons (PAHs) in coffee brew samples: analytical method by GC-MS, profile, levels and sources. Food Chem Toxicol 47(4):819-826

Padilla-Sánchez JA, Plaza-bolaños P, Frenich AG (2013) Advanced extraction techniques in environmental analysis. In: Ferrer I, Thurman M (eds) Advanced Techniques in Gas Chromatography-Mass Spectrometry (GC-MS-MS and GC-TOF-MS) for Environmental Chemistry. Elsevier, pp 184-189

Paris A, Ledauphin J, Poinot P, Gaillard JL (2018) Polycyclic aromatic hydrocarbons in fruits and vegetables: origin, analysis, and occurrence. Environ Pollut 234:96-106

Perelló G, Martí-Cid R, Castell V, Llobet JM, Domingo JL (2009) Concentrations of polybrominated diphenyl ethers, hexachlorobenzene and polycyclic aromatic hydrocarbons in various foodstuffs before and after cooking. Food Chem Toxicol 47:709-715

Phan Thi LA, Ngoc NT, Quynh NT, Thanh NVan, Kim TT, Anh DH, Viet PH, (2020) Polycyclic aromatic hydrocarbons (PAHs) in dry tea leaves and tea infusions in Vietnam: contamination levels and dietary risk assessment. Environ Geochem Health 42(9):2853-2863

Pincemaille J, Schummer C, Heinen E, Moris G (2014) Determination of polycyclic aromatic hydrocarbons in smoked and non-smoked black teas and tea infusions. Food Chem 145:807-813

Pissinatti R, Nunes CM, de Souza AG, Junqueira RG, de Souza SVC (2015) Simultaneous analysis of 10 polycyclic aromatic hydrocarbons in roasted coffee by isotope dilution gas chromatography-mass spectrometry: optimization, in-house method validation and application to an exploratory study. Food Control $51: 140-148$

Pittler MH (2005) Evidence of effectiveness for popular herbal medicines. Herba Pol 51(1/2):60-65

Plaza-Bolaños P, Frenich AG, Vidal JLM (2010) Polycyclic aromatic hydrocarbons in food and beverages. Analytical Methods and Trends. J Chromatogr A 1217(41):6303-6326

Purcaro G, Moret S, Conte LS (2007) Rapid validated for the analysis of benzo [a] pyrene in vegetable oils by using solid-phase microextraction-gas chromatography-mass spectrometry. J Chromatogr A 1176:231-235

Purcaro G, Moret S, Conte LS (2013) Overview on polycyclic aromatic hydrocarbons: occurrence, legislation and innovation determination in foods. Talanta 105:292-305

Quigley A, Cummins W, Connolly D (2016) Dispersive liquid-liquid microextraction in the analysis of milk and dairy products: a review. J Chem 2016:1-12

Ramesh A, Harris KJ, Archibong AE (2017) Reproductive toxicity of polycylic aromatic hydrocarbons. In: Gupta RC (ed) Reproductive and Developmental Toxicology. Academic press, Cambridge, pp 745-763

Rani J, Indrajeet RA, Kumar S (2020) Biovalorization of winery industry waste to produce value-added products. In: Rathinam NK, Sani RK (eds) Biovalorisation of wastes to renewable chemicals and biofuels. Elsevier, Amsterdam, pp 77-78

Rascón AJ, Azzouz A, Ballesteros E (2019) Use of semi-automated continuous solid-phase extraction and gas chromatography-mass spectrometry for the determination of polycyclic aromatic hydrocarbons in alcoholic and non-alcoholic drinks from Andalucía (Spain). J Sci Food Agric 99(3):1117-1125

Rawash EA, Mohamed GG, Souya ER, Khalil LH, El-Chaghaby GA, El-Gammal MH (2018) Distribution and health hazards of polycyclic aromatic hydrocarbons in Egyptian milk and dairy-based products. Beverages 4(3):63

Raza N, Kim KH (2018) Quantification techniques for Important environmental contaminants in milk and dairy products. TrAC Trends Anal Chem 98:79-94

Rejczak T, Tuzimski TA (2015) Review of recent developments and trends in the QuEChERS sample preparation approach. Open Chem 13(1):980-1010

Resende dos Santos R, Orlando RM, de Lourdes Cardeal Z, Menezes HC (2021) Assessment of polycyclic aromatic hydrocarbons and derivatives in beer using a new cold fiber-solid phase microextraction system. Food Control 126

Rey-Salgueiro L, Martínez-Carballo E, García-Falcón MS, GonzálezBarreiro C, Simal-Gándara J (2009) Occurrence of polycyclic aromatic hydrocarbons and their hydroxylated metabolites in infant foods. Food Chem 115:814-819

Riachi LG, Santos A, Moreira RF, De Maria CB (2014) A review of ethyl carbamate and polycyclic aromatic hydrocarbon 
contamination risk in Cachaça and other Brazilian sugarcane spirits. Food Chem 149:159-169

Ridgway K, Smith RM, Lalljie SPD (2012) 3.40-Sample preparation for food contaminant analysis. In: Pawliszyn J (ed) Comprehensive sampling and sample preparation. Academic press, Cambridge, pp 819-833

Rivera-Vera C, Lasarte-Aragonés G, Bravo MA, Muñoz-Lira D, Salazar R, Toledo-Neira C (2019) Ionic liquids-based dispersive liquid-liquid microextraction for determination of carcinogenic polycyclic aromatic hydrocarbons in tea beverages: evaluation of infusion preparation on pollutants release. Food Control 106

Rodrigues M, Fortuna A, Falcão A, Alves G (2019) Microextraction Techniques in LC-MS Bioanalysis. In: Li W, Jian W, Fu Y (eds) Sample preparation in LC-MS bioanalysis. Wiley, pp 98-113

Rodríguez-Acuña R, Pérez-Camino MDC, Cert A, Moreda W (2008) Sources of contamination by polycyclic aromatic hydrocarbons in Spanish virgin olive oils. Food Addit Contam Part A Chem Anal Control Expo Risk Assess 25(1):115-122

Roszko M, Kaminska M, Szymczyk K, Jędrzejczak R (2018) Dietary risk evaluation for 28 polycyclic aromatic hydrocarbons (Pahs) in tea preparations made of teas available on the Polish retail market. J Environ Sci Health Part B Pestic Food Contam Agric Wastes 53(1):25-34

Roudbari A, Rafiei Nazari R, Shariatifar N, Moazzen M, Abdolshahi A, Mirzamohammadi S, Madani-Tonekaboni M, Delvarianzadeh M, Arabameri M (2020) Concentration and health risk assessment of polycyclic aromatic hydrocarbons in commercial tea and coffee samples marketed in Iran. Environ Sci Pollut Res 48:4827-4839

Sadowska-Rociek A, Surma M, Cieślik E (2014) Comparison of different modifications on QuEChERS sample preparation method for PAHs determination in black, green, red and white tea. Environ Sci Pollut Res 21(2):1326-1338

Sadowska-Rociek A, Surma M, Cieślik E (2015) Determination of polycyclic aromatic hydrocarbons in coffee and coffee substitutes using dispersive SPE and gas chromatography-mass spectrometry. Food Anal Methods 8(1):109-121

Sander C, Wise A (2020) NIST Special Publication 922, Polycyclic Aromatic Hydrocarbon Structure Index. https://nvlpubs.nist.gov/ nistpubs/SpecialPublications/NIST.SP.922e2020.pdf

Santonicola S, Albrizio S, Murru N, Ferrante MC, Mercogliano R (2017) Study on the occurrence of polycyclic aromatic hydrocarbons in milk and meat/fish based baby food available in Italy. Chemosphere 184:467-472

Sasidharan S, Shanmugapriya, Jothy SL, Vijayarathna S, Kavitha N, Oon CE, Chen Y, Dharmaraj S, Lai NS, Kanwar JR (2018) Conventional and non-conventional approach towards the extraction of bioorganic phase. In: Roopan SM, Madhumitha G (ed) Bioorganic phase in natural food: An overview. Springer, pp 41-58

Schlemitz S, Pfannhauser W (1997) Supercritical fluid extraction of mononitrated polycyclic aromatic hydrocarbons from teas correlation with the PAH concentration. Z Lebensm Unters Forsch A 205:305-310

Schulz CM, Fritz H, Ruthenschrör A (2014) Occurrence of $15+1$ EU priority polycyclic aromatic hydrocarbons $(\mathrm{PAH})$ in various types of tea (Camellia sinensis) and herbal infusions. Food Addit Contam - Part A Chem Anal Control Expo Risk Assess 31(10):1723-1735

Hawach Scientific (2010) Characteristics of the QuEChERS method. https://www.hawachquechers.com/characteristics-of-the-quech ers-method/

Shang D, Kim M, Haberl M (2014) Rapid and sensitive method for the determination of polycyclic aromatic hydrocarbons in soils using pseudo multiple reaction monitoring gas chromatography/tandem mass spectrometry. J Chromatogr A 1334:118-125

Shariatifar N, Dadgar M, Fakhri Y, Shahsavari S, Moazzen M, Ahmadloo, M, Kiani A, Aeenehvand S, Nazmara S, Mousavi Khanegah
A (2020) Levels of polycyclic aromatic hydrocarbons in milk and milk powder samples and their likely risk assessment in Iranian population. J Food Compos Anal 85

Shi Y, Wu H, Wang C, Guo X, Du J, Du L (2016) Determination of polycyclic aromatic hydrocarbons in coffee and tea samples by magnetic solid-phase extraction coupled with HPLC-FLD. Food Chem 199:75-80

Sibiya P, Potgieter M, Cukrowska E, Jönsson JÅ, Chimuka L (2012) Development and application of solid phase extraction method for polycyclic aromatic hydrocarbons in water samples in Johannesburg Area, Southc Africa. S Afr J Chem 65:206-213

Singh L, Varshney JG, Agarwal T (2016) Polycyclic aromatic hydrocarbons' formation and occurrence in processed food. Food Chem 99:768-781

Skláršová B, Šimon P, Kolek E, Šimko P, Bednáriková A (2012) Nonisothermal kinetics of benzo[a]pyrene photooxidation in glyceryl trioctanoate. Polycyclic Aromat Compd 32:580-588

Smith KEC, Thomas GO, Jones KC (2001) Seasonal and species differences in the air-pasture transfer of PAHs. Environ Sci Technol 35:2156-2165

Sun Y, Yan K, Wu S, Gong G (2020) Occurrence, spatial distribution and impact factors of 16 polycyclic aromatic hydrocarbons in milks from nine countries. Food Control. https://doi.org/10. 1016/j.foodcont.2020.107197

Tala W, Chantara S (2019) Effective solid phase extraction using centrifugation combined with a vacuum-based method for ambient gasesous PAHs. New J Chem 43(47)

Tamakawa K (2004) Polycyclic aromatic hydrocarbons in food. In: Nollet LML (ed) Handbook of food analysis. Marcel Dekker, USA, pp 1449-1483

Tamakawa K (2008) Polycyclic Aromatic Hydrocarbons. In: Picó Y (ed) Food contaminants and residue analysis, 1st edn. Elsevier, Amsterdam, pp 599-644

Tamakawa K, Seki T, Tsunoda A (1992) HPLC detection of polycyclic aromatic hydrocarbons. In: Nollet LML (ed) Food Analysis By HPLC. Marcel Dekker, New York, pp 697-711

Tatatsuki K, Suzuki S, Sato N, Ushizawa I (1985) Liquid chromatography determination of polycyclic aromatic hydrocarbons in fish and shellfish. J Assoc off Anal Chem 68:945-949

Telgheder U, Bader N, Alshelmani N (2018) Stir bar sorptive extraction as a sample preparation technique for chromatographic analysis: An overview. Asian j Nanosci 1(2):54-60

Tfouni SAV, Machado RMD, Camargo MCR, Vitorino SHP, Vicente E, Toledo MCF (2007) Determination of polycyclic aromatic hydrocarbons in Cachaça by HPLC with fluorescence detection. Food Chem 101(1):334-338

Tfouni SAV, Serrate CS, Carreiro LB, Camargo MCR, Teles CRA, Cipolli KMVAB, Furlani RPZ (2012) Effect of roasting on chlorogenic acids, caffeine and polycyclic aromatic hydrocarbons levels in two coffea cultivars: coffea arabica cv. Catuaí Amarelo IAC-62 and coffea canephora cv. Apoatã IAC-2258. Int J Food Sci Technol 47(2):406-415

Tfouni SAV, Serrate CS, Leme FM, Camargo MCR, Teles CRA, Cipolli KMVAB, Furlani RPZ (2013) Polycyclic aromatic hydrocarbons in coffee brew: influence of roasting and brewing procedures in two coffea cultivars. LWT Food Sci Technol 50(2):526-530

Tfouni SAV, Reis RM, Kamikata K, Gomes FML, Morgano MA, Furlani RPZ (2018) Polycyclic aromatic hydrocarbons in teas using QuEChERS and HPLC-FLD. Food Addit Contam Part B Surveill 11(2):146-152

Thea AE, Ferreira D, Brumovsky LA, Schmalko ME (2016) Polycyclic aromatic hydrocarbons (PAHs) in yerba maté (Ilex Paraguariensis St. Hil) traditional infusions (Mate and Tereré). Food Control 60:215-220

Tran-Lam TT, Dao YH, Nguyen LKT, Ma HK, Tran HN, Le GT (2018) Simultaneous determination of 18 polycyclic aromatic 
hydrocarbons in daily foods (Hanoi Metropolitan Area) by gas chromatography-tandem mass spectrometry. Foods 7(12)

Veggi PC, Martinez J, Meireles MAA (2013) Fundamentals of microwave extraction. In: Chemat F, Cravotto G (eds) Microwaveassisted extraction for bioactive compounds. Springer, pp 15-52

Vidal M, Domínguez J, Luís A (2011) Spatial and temporal patterns of polycyclic aromatic hydrocarbons (PAHs) in eggs of a coastal bird from northwestern Iberia after a major oil spill. Sci Total Environ 409(13):2668-2673

Viegas O, Pinho O, Ferreira IMPLVO (2019) Polycyclic aromatic hydrocarbons. In: Farah A (ed) Coffee Production, Quality and Chemistry. The royal society of Chemistry, UK, pp 705-723

Vieira MA, Maraschin M, Rovaris ÂA, de Mello Castanho Amboni RD, Pagliosa CM, Xavier JJM, Amante ER (2010) Occurrence of polycyclic aromatic hydrocarbons throughout the processing stages of erva-mate (Ilex Paraguariensis). Food Addit Contam Part A Chem Anal Control Expo Risk Assess 27(6):776-782

Viñas P, Campillo N, Aguinaga N, Pérez-Cánovas E, HernándezCórdoba M (2007) Use of headspace solid-phase microextraction coupled to liquid chromatography for the analysis of polycyclic aromatic hydrocarbons in tea infusions. J Chromatogr A 1164(1-2):10-17

WHO (1998) Environmental Health Criteria (EHC) Monographs 202: Selected Non-heterocyclic Aromatic Hydrocarbons. Geneva, pp 47-96

WHO (2014) Global status report on alcohol and health. Geneva

Wierucka M, Biziuk M (2014) Application of magnetic nanoparticles for magnetic solid-phase extraction in preparing biological, environmental and food samples. TrAC 59:50-58

Will C, Huelsmann RD, da Cunha HC, Carasek E, Martendal E (2018) Improvement of dispersive liquid-liquid microextraction robustness by performing consecutive extractions: determination of polycyclic aromatic hydrocarbons in Brazilian sugar cane spirits by GC-MS. Sep Sci plus 1(8):564-573

Wu P, Zhang L, Hu Z, Zhang N, Wang L, Zhao Y (2020) Contamination of $15+1$ European Union polycyclic aromatic hydrocarbons in various types of tea and their infusions purchased on Hangzhou City Market in China. Food Addit Contam Part A Chem Anal Control Expo Risk Assess 37(10):1621-1632

Yebra-Pimentel I, Fernández-González R, Martínez Carballo E, SimalGándara J (2012) Searching ingredients polluted by polycyclic aromatic hydrocarbons in feeds due to atmospheric or pyrolytic sources. Food Chem 135:2043-2051
Yousefi M, Shemshadi G, Khorshidian N, Ghasemzadeh-Mohammadi V, Fakhri Y, Hosseini H, Mousavi Khaneghah A (2018) Polycyclic aromatic hydrocarbons (PAHs) content of edible vegetable oils in Iran: a risk assessment study. Food Chem Toxicol 118:480-489

Yu H, Li T, Liu Y, Ma L (2019) Spatial distribution of polycyclic aromatic hydrocarbon contamination in urban soil of China. Chemosphere 230:498-509

Zachara A, Gałkowska D, Juszczak L (2017) Contamination of smoked meat and fish products from Polish market with polycyclic aromatic hydrocarbons. Food Control 80:45-51

Zachara A, Gałkowska D, Juszczak L (2018) Contamination of tea and tea infusion with polycyclic aromatic hydrocarbons. Int J Environ Res Public Health 15(1):45

Zelinkova Z, Wenzl T (2015) The occurrence of 16 EPA PAHs in fooda review. Polycycl Aromat Compd 35(2-4):248-284

Zhang L, Dong L, Ren L, Shi S, Zhou L, Zhang T (2012) Concentration and source identification of polycyclic aromatic hydrocarbons and phthalic acid esters in the surface water of the Yangtze River Delta, China. J Environ Sci 24:335-342

Zhao X, Wu SM, Gong GY, Li G, Zhuang L (2017) TBHQ and peanut skin inhibit accumulation of PAHs and oxygenated PAHs in peanuts during frying. Food Control 75:99-107

Zhao X, Gong G, Wu S (2018) Effect of storage time and temperature on parent and oxygenated polycyclic aromatic hydrocarbons in crude and refined vegetable oils. Food Chem 239:781-788

Zhou DB, Sheng X, Han F, Hu YY, Ding L, Lv YL, Song W, Zheng P (2018) Magnetic solid-phase extraction based on [60]Fullerene functionalization of magnetic nanoparticles for the determination of sixteen polycyclic aromatic hydrocarbons in tea samples. J Chromatogr A 1578:53-60

Ziegenhals K, Jira W, Speer K (2008) Polycyclic aromatic hydrocarbons $(\mathrm{PAH})$ in various types of tea. Eur Food Res Technol 228(1):83-91

Zuin VG, Montero L, Bauer C, Popp P (2005) Stir bar sorptive extraction and high-performance liquid chromatography-fluorescence detection for the determination of polycyclic aromatic hydrocarbons in mate teas. J Chromatogr A 1091(1-2):2-10

Publisher's Note Springer Nature remains neutral with regard to jurisdictional claims in published maps and institutional affiliations. 